\title{
Effect of rbST on Serum Biochemical Values During Various Physiological and Weather Conditions in Kundhi Buffaloes
}

\author{
A.B. Kachiwal ${ }^{1, *}$, B.A. Sheikh ${ }^{1}$, S.A. Sheikh ${ }^{1}$, T.A. Qureshi ${ }^{1}$ and K.H. Memon ${ }^{2}$ \\ ${ }^{1}$ Sindh Agriculture University Tandojam, Pakistan \\ ${ }^{2}$ Baqai College of Veterinary Sciences, Karachi, Pakistan
}

\begin{abstract}
This study was performed to investigate the effect of rbST treatment on some biochemical parameters in addition to values of thyroid hormones in Kundhi buffaloes. Sixteen Kundhi buffaloes were divided into two groups. Group-A ( $\mathrm{N}=8)$ served as control and Group-B $(\mathrm{N}=8)$ was treated with $250 \mathrm{mg}$ of rbST fortnightly for $1^{\text {st }}$ lactation. Blood samples were collected weekly during lactation period from day one to 60 as pre-treatment values and then from day 61 to completion of $1^{\text {st }}$ lactation in Kundhi buffaloes as post-treatment values. The findings revealed overall non significant variation in the serum biochemical and thyroid hormone values between control and rbST treated buffaloes, whereas, significant differences were observed during various physiological and weather conditions in both groups. Glucose and uric acid values were observed higher during parturition and winter season in Kundhi buffaloes. Protein level was higher in rbST treated buffaloes during open days.
\end{abstract}

Keywords: Serum Biochemical values, Kundhi buffaloes, rbST, growth hormone.

\section{INTRODUCTION}

The first major livestock related product of biotechnology research was bovine somatotropin (bST). Use of recombinant bovine somatotropin (rbST) as a powerful tool to enhance cattle performance in terms of milk production has been extensively reviewed by Peel and Bauman [1], Radcliff et al., [2], Van Baale et al., [3], Prasad and Singh, [4], Abdelrahman et al., [5], Macrina et al., [6] and Mellado et al. [7] and in buffaloes by (Helal and Lasheen, [8] and Khaliq and Rehman, [9]. Mean volume injected have varied from 5 to $50 \mathrm{mg} /$ day (Peel and Bauman [1], Radcliff et al., [2], Van Baale et al., [3], Prasad and Singh, [4], Abdelrahman et al., [5], Macrina et al., [6] and Mellado et al. [7]). While most studies either pertain to cattle, crossbred animals (Chalupa et al., [10] and Radchiff et al., [2]) and to some extent with sheep (Fernandez et al., [11]) and goats (Disenhaus et al., [12]). Blood biochemical parameters are very important indicators of the health condition and metabolic activity in lactating animals (Sobiech et al., [13] and Karapehlivan, et al., [14]). Variations of blood biochemical values in animals are due to several factors such as altitude, feeding level, age, sex, breed, diurnal and seasonal variation, temperature and physiological status of animals (Mbassa et al., [15]). Thyroid hormones also play a relatively important role in pregnancy and lactation and involved in the metabolic response via maintaining the homeostasis of energy and protein metabolism, thermoregulation,

*Address correspondence to this author at the Sindh Agriculture University Tandojam, Pakistan; Tel: +9222765415; Fax: +922765300;

E-mail: kachiwal2003@gmail.com growth and productivity (Huszenicza et al., [16]). Monitoring the serum biochemical profile and thyroid hormones in animals gives a clear picture of their nutritional and health status before the changes are visible on the animal (Antunovic et al., [17]). Blood is an important and reliable medium for assessing the health status in individual animal (Ramprabhu et al., [18]). Serum biochemical tests are widely used for the diagnosis of serious animal diseases which can lead to economic losses in animals like reduced fur, wool and milk production (Bani et al., [19]). As limited information is available regarding the serum biochemical profile of Kundhi buffaloes in Pakistan, the aim of the present study was to investigate the effect of rbST treatment on some serum biochemical parameters in addition to level of thyroid hormones in Kundhi buffaloes.

\section{MATERIALS AND METHODS}

The experiment was performed on sixteen Kundhi buffaloes (primaparous) of with mean age of $1464.75 \pm$ 12.75 days and weighing $461 \pm 35.24 \mathrm{~kg}$ to evaluate the effect of rbST on biochemical parameters during $1^{\text {st }}$ lactation. Buffaloes were purchased from surrounding markets of Tandojam and kept at Livestock Experimental Station, Faculty of Animal Husbandry and Veterinary Sciences, Sindh Agriculture University Tandojam for this study. The herd was vaccinated against FMD and $\mathrm{HS}$ as pre schedule of vaccination and dewormed regularly during the experimental period. Balancing of rations was computed by the method of: National Research Council 1978 as described in the nutrient requirements of Dairy cattle, Academy of Sciences, National Research Council,

() 2015 Lifescience Global 
Washington DC. Nutritive values of components of feed ingredients such as Fat, Crude Protein, TDN, Crude Fiber and Ash, were analyzed by the standard methods described in (AOAC, [20]). Buffaloes were housed in individual tied stalls with free access to water. Buffaloes were fed twice daily ad libitum with access to a total mixed ration consisting of $61 \%$ dry matter (Table 1). The data on daily feed intake and feed refused were weighed and recorded on the record book. Strict hygienic measures were followed during milking of buffaloes twice daily which was recorded on day to day basis. Sixteen Kundhi buffaloes were divided randomly in group- $\mathrm{A}(\mathrm{N}=8)$ and group- $\mathrm{B}(\mathrm{N}=8)$ (Table 2). Group$A$ was kept as control only on balance ration containing $16 \%$ crude protein (Table 1 ) and group-B was kept on balance ration with $\mathrm{rbST} 250 \mathrm{mg} /$ buffalo/fortnightly treatment.

Blood samples for biochemical and hormonal tests were collected from jugular vein in Marble bottom and heparinized vacutainer tubes between 14:30 hrs to

Table 1: Composition of Balance Protein Energy Rations

\begin{tabular}{|c|c|}
\hline Ingredients & Balance protein energy ration \\
\hline \hline Barseem & $8 \mathrm{~kg}$ \\
\hline Wheat Straw & $4 \mathrm{~kg}$ \\
\hline Cotton Seed Cake & $3.2 \mathrm{~kg}$ \\
\hline Mustard Cake & $0.2 \mathrm{~kg}$ \\
\hline Moong Kutta & $1.0 \mathrm{~kg}$ \\
\hline Wheat Bran & $0.8 \mathrm{~kg}$ \\
\hline Maize Crushed & $0.4 \mathrm{~kg}$ \\
\hline Rice Polish & $2.0 \mathrm{~kg}$ \\
\hline Molasses & $0.4 \mathrm{~kg}$ \\
\hline Phosphate / Limestone & $0.05 \mathrm{~kg}$ \\
\hline Dry Matter & \\
\hline Crude Protein & $61 \%$ \\
\hline Di-Calcium & $16 \%$ \\
\hline Crude Fiber & $67 \%$ \\
\hline Calcium & $19 \%$ \\
\hline Phosphorus & $0.78 \%$ \\
\hline
\end{tabular}

Table 2: Experimental Design

\begin{tabular}{|c|c|c|c|c|c|}
\hline Group A & Weight (kg) & Age (days) & Group B & Weight (kg) & Age (days) \\
\hline Buffalo 1 & 509 & 1444 & Buffalo 2 & 445 & 1460 \\
\hline Buffalo 8 & 440 & 1460 & Buffalo 5 & 444 & 1488 \\
\hline Buffalo 9 & 448 & 1474 & Buffalo 7 & 448 & 1460 \\
\hline Buffalo 11 & 442 & 1480 & Buffalo 15 & 440 & 1450 \\
\hline Buffalo 3 & 432 & 1460 & Buffalo 10 & 515 & 1480 \\
\hline Buffalo 4 & 440 & 1460 & Buffalo 13 & 511 & 1470 \\
\hline Buffalo 6 & 524 & 1480 & Buffalo 14 & 433 & 1460 \\
\hline Buffalo 12 & 453 & 1460 & Buffalo 16 & 444 & 1450 \\
\hline Mean & 461 & 1464.75 & & 460 & 1464.75 \\
\hline SEM & 35.03 & 12.37 & & 33.03 & 13.65 \\
\hline
\end{tabular}


15:30 hrs on one day in each week and body weights were recorded. Samples were placed on ice immediately after collection, centrifuged within 2 hours at 3,000 rpm for 30 minutes at $5{ }^{\circ} \mathrm{C}$ (Jouan GR 412 centrifuge, Winchester, VA) and plasma collected and stored in polypropylene tubes at $-20{ }^{\circ} \mathrm{C}$ until analyzed. They were carried to the Postgraduate Research Laboratory in the Department of Veterinary Physiology and Biochemistry, Faculty of Animal Husbandry and Veterinary Sciences, Sindh Agriculture University Tandojam, Pakistan. Double antibody radioimmunoassay and Enzyme linked immunoassay procedures were used to determine concentrations of progesterone, Tri-iodothyronine $\left(T_{3}\right)$, Thyroxine $\left(T_{4}\right)$. Serum Glucose, Protein, Calcium, Lipid, Cholesterol, Uric Acid, Sodium and Potassium were determined by using an UV/VIS double Beam spectophotometer, (Hitachi U-2800, Japan).

Statistical package Mini Tab (version 16) was used for statistical analysis. All the values were expressed as mean \pm standard error (SE). One way ANOVA was applied to compare various biochemical parameters. These parameters were also calculated to determine the effect of rbST on the serum biochemical values in addition to thyroid hormones of primaparous Kundhi buffaloes.

\section{RESULTS}

Serum Biochemical and hormonal parameters including Glucose, Protein, Calcium, Lipid, Cholesterol,

Table 3: Pre-Treatment Values of Hormones and Serum Biochemical Parameters During $1^{\text {st }}$ Lactation in Kundhi Buffaloes

\begin{tabular}{|c|c|c|}
\hline Pre-treatment & Group-A (Control) & Group-B (rbST) \\
\cline { 2 - 3 } & Mean \pm SE & Mean \pm SE \\
\hline \hline Glucose $(\mathrm{mg} / \mathrm{dl})$ & $53.35 \pm 15.215$ & $6.35 \pm 0.725$ \\
\hline Protein $(\mathrm{mg} / \mathrm{dl})$ & $6.25 \pm 0.61$ & $6.95 \pm 1.075$ \\
\hline Calcium $(\mathrm{mg} / \mathrm{dl})$ & $7.95 \pm 1.29$ & $554 \pm 91.33$ \\
\hline Lipid $(\mathrm{mg} / \mathrm{dl})$ & $549.8 \pm 84.43$ & $420.35 \pm 40.7$ \\
\hline Cholesterol $(\mathrm{mg} / \mathrm{dl})$ & $413.25 \pm 41.075$ & $8.9 \pm 1.34$ \\
\hline Uric Acid $(\mathrm{mg} / \mathrm{dl})$ & $8.25 \pm 1.435$ & $144.57 \pm 18.53$ \\
\hline Sodium $\mathrm{mmol} / \mathrm{L}$ & $150.47 \pm 25.48$ & $5.78 \pm 0.52$ \\
\hline Potassium $\mathrm{mmol} / \mathrm{L}$ & $5.4 \pm 0.75$ & $1.85 \pm 0.48$ \\
\hline T3 $(\mathrm{n} \mathrm{mol} / \mathrm{L})$ & $1.5 \pm 0.22$ & $16.4 \pm 6.05$ \\
\hline T4 $(\mathrm{n} \mathrm{mol} / \mathrm{L})$ & $13.5 \pm 5.83$ & $0.06 \pm 0.13$ \\
\hline GH $(\mu \mathrm{l} / \mathrm{L})$ & $0.05 \pm 0.05$ & $0.75 \pm 1.35$ \\
\hline
\end{tabular}

Table 4: Effect of rbST Treatment on Hormones and Blood Biochemical Parameters During $1^{\text {st }}$ Lactation in Kundhi Buffaloes

\begin{tabular}{|c|c|c|}
\hline \multirow{2}{*}{ Post-treatment } & Group-A (Control) & Group-B (rbST) \\
\cline { 2 - 3 } & Mean \pm SE & $67.1 \pm 23.21$ \\
\hline \hline Glucose $(\mathrm{mg} / \mathrm{dl})$ & $65 \pm 21.895$ & $6.85 \pm 1.22$ \\
\hline Protein $(\mathrm{mg} / \mathrm{dl})$ & $6.35 \pm 0.8$ & $7.5 \pm 1.375$ \\
\hline Calcium $(\mathrm{mg} / \mathrm{dl})$ & $7.8 \pm 1.135$ & $610.45 \pm 128.075$ \\
\hline Lipid $(\mathrm{mg} / \mathrm{dl})$ & $663.9 \pm 100.085$ & $408.25 \pm 41.71$ \\
\hline Cholesterol $(\mathrm{mg} / \mathrm{dl})$ & $393.15 \pm 41.165$ & $9.85 \pm 0.79$ \\
\hline Uric Acid $(\mathrm{mg} / \mathrm{dl})$ & $9.5 \pm 0.635$ & $141.65 \pm 26.505$ \\
\hline Sodium $\mathrm{mmol} / \mathrm{L}$ & $144.1 \pm 24.14$ & $5.25 \pm 1.255$ \\
\hline Potassium $\mathrm{mmol} / \mathrm{L}$ & $5.4 \pm 1.35$ & $1.85 \pm 0.33$ \\
\hline T3 $(\mathrm{n} \mathrm{mol} / \mathrm{L})$ & $1.35 \pm 0.21$ & $17.4 \pm 5.755$ \\
\hline T4 $(\mathrm{n} \mathrm{mol} / \mathrm{L})$ & $13 \pm 5.575$ & $0.1 \pm 0.135$ \\
\hline GH $(\mu / \mathrm{L} / \mathrm{L})$ & $0.1 \pm 0.005$ & $6.355 \pm 9.232$ \\
\hline PROGESTRONE $(\mathrm{ng} / \mathrm{mL})$ & $5.5 \pm 7.915$ & \\
\hline
\end{tabular}

${ }^{* *}=$ Values were significantly low $(\mathrm{P}<0.01)$ than the corresponding control. 
Uric Acid, Sodium, Potassium, T3, T4, serum GH and Serum progesterone are demonstrated in (Tables 3 to 11). The comparison of serum biochemical and hormonal parameters are shown in (Tables 3 and 4). The values of glucose, calcium, protein, lipid, cholesterol and uric acid remained unaffected after rbST treatment. There was no significant effect on T3 and T4 in rbST treated buffaloes. Progesterone level was elevated in both groups in pregnant buffaloes but there was no significant difference in the values of progesterone of control and rbST treated animals. No abnormal health characteristics were noted during pre or post rbST treatment. Inspection of implantation site indicated occasional local and transient swelling. The glucose concentration was significantly higher in group$B$ than group-A during parturition (Table 5). The blood biochemical values fluctuation during various physiological conditions and weather are demonstrated in (Tables 5 to 11). Glucose and uric acid values were observed higher during parturition and winter season in Kundhi buffaloes. Protein level was significantly higher $(P<0.05)$ in rbST treated buffaloes during open days than the values of control group during various physiological and weather conditions. Calcium values were higher during open days, parturition days, conception days and dry period than the values of lactation period, winter and summer seasons. Calcium values of rbST treated buffaloes were lower than the values of control buffaloes. Cholestrol and uric acid values were higher in winter season than the values of summer season in both groups of buffaloes.

\section{DISCUSSION}

There is little scientific literature available on the effect of rbST on hormonal parameters in buffaloes. The literature on plasma progesterone concentrations in the last stages of gestation is rather conflicting. In this study clear increase in progesterone level in both groups is observed and significant increase $(P<0.01)$ on day 18 (Tables 3 and $\mathbf{4}$ ). Similarly a clear increase of progesterone concentration was reported during the last 15-30 days (Perera, et al., [21], Kamonpatana, [22], Momongan, et al., [23]). Peak values noted were

Table 5: Effect of rbST Treatment on Blood Biochemical Values During Parturition in Kundhi Buffalo

\begin{tabular}{|c|c|c|}
\hline \multirow{2}{*}{ Biochemical parameters } & Group-A (Control) & Group-B (rbST treated) \\
\cline { 2 - 3 } & Mean \pm SE & $80.4 \pm 19.49$ \\
\hline \hline Glucose $(\mathrm{mg} / \mathrm{dl})$ & $65.8 \pm 9.97$ & $6.60 \pm 1.16$ \\
\hline Protein $(\mathrm{mg} / \mathrm{dl})$ & $6.3 \pm 0.74$ & $7.1 \pm 1.44$ \\
\hline Calcium $(\mathrm{mg} / \mathrm{dl})$ & $7.8 \pm 1.91$ & $576.4 \pm 65.77$ \\
\hline Lipid $(\mathrm{mg} / \mathrm{dl})$ & $523.3 \pm 72.39$ & $355.7 \pm 55.37$ \\
\hline Cholesterol $(\mathrm{mg} / \mathrm{dl})$ & $322.7 \pm 70.91$ & $8.9 \pm 0.86$ \\
\hline Uric Acid $(\mathrm{mg} / \mathrm{dl})$ & $9.2 \pm 0.53$ & $128.5 \pm 51.86$ \\
\hline Sodium $\mathrm{mmol} / \mathrm{L}$ & $148.8 \pm 25.22$ & $5.7 \pm 0.58$ \\
\hline Potassium $\mathrm{mmol} / \mathrm{L}$ & $5.5 \pm 0.80$ & \\
\hline
\end{tabular}

Table 6: Effect of rbST Treatment on Blood Biochemical Values During Conception in Kundhi Buffalo

\begin{tabular}{|c|c|c|}
\hline \multirow{2}{*}{ Biochemical parameters } & Group-A (Control) & Group-B (rbST treated) \\
\cline { 2 - 3 } & Mean \pm SE & $68.4 \pm 13.56$ \\
\hline \hline Glucose $(\mathrm{mg} / \mathrm{dl})$ & $63.6 \pm 9.38$ & $6.3 \pm 0.91$ \\
\hline Protein $(\mathrm{mg} / \mathrm{dl})$ & $6.6 \pm 0.44$ & $8.2 \pm 1.53$ \\
\hline Calcium $(\mathrm{mg} / \mathrm{dl})$ & $8.3 \pm 1.47$ & $609.1 \pm 29.19$ \\
\hline Lipid $(\mathrm{mg} / \mathrm{dl})$ & $628.0 \pm 117.10$ & $362.6 \pm 29.44$ \\
\hline Cholesterol $(\mathrm{mg} / \mathrm{dl})$ & $326.2 \pm 99.82$ & $9.6 \pm 0.70$ \\
\hline Uric Acid $(\mathrm{mg} / \mathrm{dl})$ & $9.5 \pm 0.61$ & $144.4 \pm 12.28$ \\
\hline Sodium $\mathrm{mmol} / \mathrm{L}$ & $146.4 \pm 15.22$ & $4.7 \pm 1.75$ \\
\hline Potassium $\mathrm{mmol} / \mathrm{L}$ & $5.6 \pm 0.19$ & \\
\hline
\end{tabular}


Table 7: Effect of rbST Treatment on Blood Biochemical Values of Lactating Pregnant Kundhi Buffalo

\begin{tabular}{|c|c|c|}
\hline \multirow{2}{*}{ Biochemical parameters } & Group-A (Control) & Group-B (rbST treated) \\
\cline { 2 - 3 } & Mean \pm SE & $72.4 \pm 13.79$ \\
\hline \hline Glucose $(\mathrm{mg} / \mathrm{dl})$ & $69.2 \pm 10.92$ & $6.4 \pm 0.84$ \\
\hline Protein $(\mathrm{mg} / \mathrm{dl})$ & $6.7 \pm 1.00$ & $7.4 \pm 1.32$ \\
\hline Calcium $(\mathrm{mg} / \mathrm{dl})$ & $8.4 \pm 1.46$ & $584.1 \pm 98.59$ \\
\hline Lipid $(\mathrm{mg} / \mathrm{dl})$ & $624.2 \pm 80.23$ & $373.6 \pm 64.30$ \\
\hline Cholesterol $(\mathrm{mg} / \mathrm{dl})$ & $323.3 \pm 85.19$ & $9.1 \pm 0.77$ \\
\hline Uric Acid $(\mathrm{mg} / \mathrm{dl})$ & $9.0 \pm 0.54$ & $133.4 \pm 27.40$ \\
\hline Sodium $\mathrm{mmol} / \mathrm{L}$ & $140.2 \pm 16.73$ & $5.1 \pm 0.82$ \\
\hline Potassium $\mathrm{mmol} / \mathrm{L}$ & $5.9 \pm 0.74$ & \\
\hline
\end{tabular}

Table 8: Effect of rbST Treatment on Blood Biochemical Values During Dry Period in Kundhi Buffalo

\begin{tabular}{|c|c|c|}
\hline Dionominal naramatoro & Group-A (Control) & Group-B (rbST) \\
\hline & Mean \pm SE & Mean \pm SE \\
\hline Glucose (mg/dl) & $66.2 \pm 9.91$ & $71.1 \pm 9.01$ \\
\hline Protein (mg/dl) & $6.2 \pm 0.64$ & $7.4 \pm 2.17$ \\
\hline Calcium (mg/dl) & $7.8 \pm 1.30$ & $8.0 \pm 1.29$ \\
\hline Lipid (mg/dl) & $607.1 \pm 54.15$ & $613.1 \pm 40.40$ \\
\hline Cholesterol (mg/dl) & $369.4 \pm 57.18$ & $338.4 \pm 66.96$ \\
\hline Uric Acid (mg/dl) & $8.8 \pm 0.54$ & $8.8 \pm 0.57$ \\
\hline Sodium mmol/L & $146.7 \pm 16.17$ & $130.8 \pm 24.05$ \\
\hline Potassium mmol/L & $5.4 \pm 0.57$ & $5.7 \pm 0.47$ \\
\hline
\end{tabular}

Table 9: Effect of rbST Treatment on Blood Biochemical Values During Open Days in Kundhi Buffalo

\begin{tabular}{|c|c|c|}
\hline \multirow{2}{*}{ Biochemical parameters } & Group-A (Control) & Group-B (rbST treated) \\
\cline { 2 - 3 } & Mean \pm SE & $66.6 \pm 10.04$ \\
\hline \hline Glucose $(\mathrm{mg} / \mathrm{dl})$ & $66.5 \pm 8.62$ & $6.7 \pm 0.59$ \\
\hline Protein $(\mathrm{mg} / \mathrm{dl})$ & $6.3 \pm 0.57$ & $8.6 \pm 1.43$ \\
\hline Calcium $(\mathrm{mg} / \mathrm{dl})$ & $8.5 \pm 1.30$ & $586.8 \pm 75.36$ \\
\hline Lipid $(\mathrm{mg} / \mathrm{dl})$ & $571.4 \pm 69.42$ & $312.4 \pm 92.94$ \\
\hline Cholesterol $(\mathrm{mg} / \mathrm{dl})$ & $328.4 \pm 87.03$ & $9.0 \pm 0.76$ \\
\hline Uric Acid $(\mathrm{mg} / \mathrm{dl})$ & $8.8 \pm 0.60$ & $137.9 \pm 15.84$ \\
\hline Sodium $\mathrm{mmol} / \mathrm{L}$ & $147.8 \pm 14.48$ & $5.5 \pm 0.60$ \\
\hline Potassium $\mathrm{mmol} / \mathrm{L}$ & $6.5 \pm 1.49$ & \\
\hline
\end{tabular}

$3 \pm 0.3 \mathrm{ng} / \mathrm{ml}$ on day -1 for buffalo heifers (El-Belely, et al., [24]) and $5 \mathrm{ng} / \mathrm{ml}$ on day-5 in mature buffaloes (Pathak and Janakiraman, [25]). On the contrary gradual decrease starting 17-30 days before calving (Arora and Pandey, [26], Prakash and Madan, [27], El-
Belely, et al., [24]) with sharp decline as early as 8 days (Eissa, et al., [28]) or as late as 1-3 days before parturition (Batra, et al., [29], Barkawi, et al., [30], Prakash and Madan, [27]) were described. Never the less irrespective of the above mentioned debate, in all 
Table 10: Effect of rbST Treatment on Blood Biochemical Values During Winter in Kundhi Buffalo

\begin{tabular}{|c|c|c|}
\hline \multirow{2}{*}{ Biochemical parameters } & Group-A (Control) & Group-B (rbST) \\
\cline { 2 - 3 } & Mean \pm SE & $80.8 \pm 19.06$ \\
\hline \hline Glucose $(\mathrm{mg} / \mathrm{dl})$ & $78.0 \pm 19.09$ & $6.3 \pm 1.32$ \\
\hline Protein $(\mathrm{mg} / \mathrm{dl})$ & $5.7 \pm 0.44$ & $7.1 \pm 1.27$ \\
\hline Calcium $(\mathrm{mg} / \mathrm{dl})$ & $7.3 \pm 1.19$ & $569.6 \pm 122.12$ \\
\hline Lipid $(\mathrm{mg} / \mathrm{dl})$ & $624.8 \pm 139.46$ & $405.4 \pm 45.34$ \\
\hline Cholesterol $(\mathrm{mg} / \mathrm{dl})$ & $398.9 \pm 50.38$ & $9.5 \pm 0.91$ \\
\hline Uric Acid $(\mathrm{mg} / \mathrm{dl})$ & $9.3 \pm 0.50$ & $153.2 \pm 13.52$ \\
\hline Sodium $\mathrm{mmol} / \mathrm{L}$ & $157.2 \pm 21.48$ & $5.0 \pm 1.16$ \\
\hline Potassium $\mathrm{mmol} / \mathrm{L}$ & $6.0 \pm 3.96$ & \\
\hline
\end{tabular}

Table 11: Effect of rbST Treatment on Blood Biochemical Values During Summer in Kundhi Buffalo

\begin{tabular}{|c|c|c|}
\hline \multirow{2}{*}{ Post-treatment } & Group-A (Control) & Group-B (rbST) \\
\cline { 2 - 3 } & Mean \pm SE & $74.0 \pm 10.61$ \\
\hline \hline Glucose $(\mathrm{mg} / \mathrm{dl})$ & $70.2 \pm 10.74$ & $6.1 \pm 0.63$ \\
\hline Protein $(\mathrm{mg} / \mathrm{dl})$ & $5.9 \pm 0.60$ & $7.3 \pm 1.14$ \\
\hline Calcium $(\mathrm{mg} / \mathrm{dl})$ & $7.5 \pm 1.29$ & $620.2 \pm 50.77$ \\
\hline Lipid $(\mathrm{mg} / \mathrm{dl})$ & $606.4 \pm 47.95$ & $369.8 \pm 61.68$ \\
\hline Cholesterol $(\mathrm{mg} / \mathrm{dl})$ & $376.8 \pm 55.02$ & $8.7 \pm 0.76$ \\
\hline Uric Acid $(\mathrm{mg} / \mathrm{dl})$ & $8.7 \pm 0.51$ & $144.7 \pm 12.94$ \\
\hline Sodium $\mathrm{mmol} / \mathrm{L}$ & $146.0 \pm 20.64$ & $5.7 \pm 0.70$ \\
\hline Potassium $\mathrm{mmol} / \mathrm{L}$ & $5.7 \pm 0.60$ & \\
\hline
\end{tabular}

cases a precipitous decline of progesterone level occurred on the day of calving. In some reports (Kamonpatana, [22], Prakash and Madan, [27], Momongan, et al., [23], Eissa, et al., [28] and Tiwari, et al., [31]) basal values $0.1-0.6 \mathrm{ng} / \mathrm{ml}$ were reached during calving suggesting complete luteolysis at parturition, with no significant changes during the postpartum period. In the others decline of progesterone continued during the postpartum period to reach minimum levels on day-6 (Bahga and Gangawar, [32] and Bahga, [33]) to day-15 (El-Belely, et al., [24]), indicating complete regression of the corpus luteum of pregnancy was reported by Pahwa and Pandey, [34]. Demise of the corpus luteum after calving expressed by progesterone concentration on Day-3 postpartum was no different in milked and suckled buffaloes (Arya and Madan, [35]).

In the present study, serum glucose did increase significantly while globulin concentration did decrease significantly by two consecutive injections of rbST (250 mg/14days/animal) in buffaloes. Similarly Aboin et al. [36] reported significant increase in plasma glucose in non-lactating and non-pregnant dairy cows. Helal and Lasheen [8] reported that plasma glucose concentration was significantly increased by rbST injection (500mg/animal/14days) to Egyptian Dairy Buffaloes. Gulay et al., [37] reported that treatment with rbST during postpartum period stimulate glucose metabolism in cattle. Eisemann et al. [38] did not observe any change in glucose after growth hormone injection. Variation in serum glucose concentration in rbST injected animals may be related to the dose, length of injection, number of samples being obtained after injection and above all timing of samples relative to feeding. Some of the inconsistency may also be related to the preparation of rbST, by different companies and purity of hormones. Pituitary derived rbST by recombinant DNA technology resulted in an increase conversion of propionate to glucose in liver 
slices from lactating cow (McShane et al., [39]). Alterations in serum glucose contents during pregnancy to lactation are the result of physiological changes in metabolic processes, which take place at the beginning of lactation (Zvorc et al., [40]) therefore, regulating glucose delivery and uptake limiting step of milk synthesis. This may lead to the conclusion that insulin is independent of glucose uptake and decreases for other tissues except for the mammary gland following the onset of lactation. High serum cholesterol in rbST injected buffaloes may be due to breed and lactation in addition to high dose of rbST to cause stress in high milk production. Both lipogenesis and lipolysis are affected by rbST treatment, with effects on lipid synthesis being of major importance when animals are in positive energy balance, whereas effects on lipolysis predominate when animals are at an energy balance near zero or negative. In addition, the effects of rbST on lipid metabolism are chronic rather than acute. These chronic effects predominately involve alterations in the ability of acute homeostatic signals to alter rates of lipogenesis and lipolysis. These effects appear to be a direct action of rbST on adipose tissue (Bauman and Vernon, [41]; Etherton et al., [42]). A significant decrease in overall serum urea was observed in rbST treated buffaloes as compared to control at the end of the experiment. In another study, Sallam et al., [43] reported a significant decrease in plasma urea concentration in sheep. Eisemann et al., [38] observed a non-significant change in blood urea in rbST treated cow. In another study by McShane et al., [39] a slight lowering of urea concentration at 2, 3 and 4th week of bST treatment was observed. In contrast, Annexstad et al., [44] and McGuffey et al., [45] determined slight higher serum urea in dairy cow after administration of rbST. Limited information is available about the effects of rbST on proteins metabolism of domestic animals than for either lipid or carbohydrate metabolism. It is clear that rbST treatment increases muscle proteins accretion in growing animals (Crooker et al., [46]) and reported an increase in milk protein synthesis by lactating cows (Laurent et al., [47]). A decrease in serum protein and globulin in rbST injected buffaloes may be related to high dose of rbST injected to these animals. A possible mechanism to suggest for the decrease in proteins could be the utilization of amino acids as a gluconeogenic substrate for glucose synthesis to fulfill the demand of glucose for making up of lactose to increase milk production. However Sallam et al., [43] didn't find any change in plasma protein in rbST treated sheep. On the other hand, Prasad and
Singh [4] reported that rbST treatment influenced milk proteins and lactose without affecting plasma glucose. They also mentioned that variation in milk yield, plasma glucose $(P \leq 0.01)$ and fat between buffaloes was significant $(P \leq 0.05)$. Buffaloes injected with two consecutive injections of $500 \mathrm{mg} / 16$ days of rbST did show a significant increase in ALT while AST did not show any alteration as compared to control animals. These results are similar to the finding of Reese et al., [48] and in contrast to Kudlac et al., [49] where they did observe a significant increase in AST activity during lactation. This may be due to increased metabolic activity of liver due to rbST injection, together with possible stress of lactation and energy loss, which leads liver cells to secrete ALT. However Sallam et al., [43] didn't find any change in ALT as well AST in rbST treated sheep. Triiodothyronine (T3) concentration in serum of rbST-treated buffaloes did not change. Oldenbroek et al., [50] find similar observations in cattle treated with rbST. In general, concentration of T3 and T4 in blood rises during late lactation (Baldi, [51]). A significant decrease in serum thyroxine was observed in the rbST-treated as compared to their normal buffaloes. Siget et al., [52] did not notice significant changes in the levels of T3 and T4 under the influence of application of rbST fed various levels of crude proteins. Annexstad et al., [44] reported that circulating concentration of T4 was not affected by rbST. Likewise, Johnson et al., [53] observed no changes in circulating levels of thyroxine when animals were injected with rbST. Bouda et al., [54] and Graf et al., [55] did observe similar changes in thyroxine, and values were found to be within the physiological range. Chadio et al., [56] observed no change in thyroxin level after administering rbST however a highly significant increase in T3 was observed. Schams et al., [57] did observe a similar result for thyroid hormone and are in accordance to the present study where T3 was not affected while a significant decrease in T4 was observed in dual purpose German cattle showing a negative correlation with milk production. This decrease in T4 might be due to the mechanism of animals to conserve energy by decreasing basal metabolic rate, which is typical of a dual-purpose cow (Schams et al., [57]). The few studies are available on thyroid function in late gestation and early pregnancy period in buffaloes adopted different experimental designs. In this study rbST treated buffaloes produced little bit higher concentration of $\mathrm{T}_{3}$ and $\mathrm{T}_{4}$ hormones than non treated buffaloes (Table 2). Single blood samples from different groups in various stages of 
gestation during the same period (1\&2 months) revealed minor fluctuations of $\mathrm{T}_{4}$ (Thyroxine) levels with no specific trends in Murrah buffaloes (Hung and Parkash, [58], but the levels of $\mathrm{T}_{3}$ (triodothyronine) and $\mathrm{T}_{4}$ were reported to decrease in full term (9-10 months) swamp buffaloes (Pichaicharnarong, et al., [59]). Variations between individuals and between the two types of buffaloes revealed lower level of $T_{3}$ and $T_{4}$ concentration. Treatment of lactating dairy animals may have been associated with changes in the metabolic process thereby increasing milk production. Studies conducted to determine effect of rbST treatment on biochemical parameters of Egyptian Dairy Buffaloes from 14 days before parturition until first 120 days of lactation showed significant increase in plasma protein and glucose concentrations whereas no change was noticed in plasma albumin, albumin/globulin ratio, urea, Glutamine Oxalate transaminase (GOT), Glutamine Pyruvate trasaminase (GPT) and cholesterol content between treated and control buffaloes (Helal and Lasheen, [8]).

\section{REFERENCES}

[1] Peel CJ, Bauman D. Erythrocytes, somatotropin and lactation. J Dairy Sci 1987; 70: 474-486. http://dx.doi.org/10.3168/ids.S0022-0302(87)80030-9

[2] Radcliff RP, Vandehaar MJ, Chapin LT, Pilbean TE, Beede DK, Stanisiewski EP, Tuker HA. Effect of diet and injection of bovine somatotropin on prepubertal growth and first lactation milk yields of Holstein cows. J Dairy Sci 2000; 83: 23-29. http://dx.doi.org/10.3168/jds.S0022-0302(00)74850-8

[3] Van Baale MJ, Ledwith DR, Thompson JM, Burgos R, Collier $\mathrm{RJ}$, Baumgard LH. Effect of increased milking frequency in early lactation with or without recombinant bovine somatotropin. J Dairy Sci 2005; 88: 3905-3912. http://dx.doi.org/10.3168/jds.S0022-0302(05)73076-9

[4] Prasad J, Singh M. Milk production and hormonal changes in Murrah Buffaloes administered recombinant Bovine Somatotropin (rBST) Agric. Biol JN Am 2010; 1(6): 13251327.

http://dx.doi.org/10.5251/abjna.2010.1.6.1325.1327

[5] Abdelrahman AH, Khalil AS, EL-Hamamsy HT, Ezzo OH. The Effect of Recombinant Bovine Somatotropin Administration on Milk Production, Some HematoBiochemical Parameters and Reproductive Performance of Lactating Cows. Global Veterinaria 2010; 4(4): 366-373.

[6] Macrina AL, Tozer PR, Kensinger RS. Induced lactation in pubertal heifers: Efficacy, response to bovine somatotropin, and profitability. J Dairy Sci 2011; 94(3): 1355-1364. http://dx.doi.org/10.3168/jds.2010-3811

[7] Mellado M, Antonio-Chirino E, Meza-Herrera C, Veliz FG, Arevalo JR, Mellado J, de Santiago A. Effect of lactation number, year, and season of initiation of lactation on milk yield of cows hormonally induced into lactation and treated with recombinant bovine somatotropin. J Dairy Sci 2011; 94(9): 4524-4530.

http://dx.doi.org/10.3168/jds.2011-4152

[8] Helal FIS, Lasheen MA. The productivity performance of Egyptian dairy buffaloes receiving biosynthetic bovine somatotropin (rbST) with or without monensin. Am Eur J Agric Environ Sci 2008; 3: 771-777.

[9] Khaliq T, Rahman ZU. Haematological Studies of Nili-Ravi Buffaloes Injected with Recombinant Bovine Somatotropin. Pakistan Vet J 2010; 30(1): 53-57.

[10] Chalupa W, Vecchaivelli B, Gallian D, Ferguson TJD, Baird LS, Hemken RW, Harmon RW, Harmon RJ, Soderholm CG, Otterby DE, Annexstad RJ, Linn JG, Hansen WP, Ehla, Palmquist DL, Eggert RG. Response of dairy cows supplemented with somatotropin during weeks 5 through 43 of lactation. J Dairy Sci 1996; 79: 800-812. http://dx.doi.org/10.3168/jds.S0022-0302(96)76428-7

[11] Fernandez NM, Rodringuez I, Peris C, Barcelo M, Molina MP, Torres A. Bovine somatotropin dose titration in lactating dairy ewes. J Dairy Sci 1995; 78: 1073-1082. http://dx.doi.org/10.3168/ids.S0022-0302(95)76724-8

[12] Disenhaus CH, Herveu J, Ternois F, Sauvant D. Effect of recombinant bovine somatotropin on goat milk yield, composition and plasma metabolites. Small Rumin Res 1995; 15: 139-148.

http://dx.doi.org/10.1016/0921-4488(94)00019-4

[13] Sobiech P, Milewski S, Zduńczyk S. Yield and composition of milk and blood biochemical components of ewes nursing a single lamb or twins. Bull Vet Inst Pulawy 2008; 52: 591-596.

[14] Karapehlivan M, Atakisi A, Atakisi O, Yucayurt R, Pancarci SM. Blood biochemical parameters during the lactation and dry period in Tuj ewes. Small Rum Res 2007; 73: 267-271. http://dx.doi.org/10.1016/..smallrumres.2006.12.006

[15] Mbassa GK, Poulsen JSD. Reference ranges for clinical chemical values in Landrace goats. Small Rumin Res 2003; 10: 133-142.

http://dx.doi.org/10.1016/0921-4488(93)90056-N

[16] Huszennicza GY, Kulcsar M, Rudas P. Clinical endocrinology of thyroid gland function in ruminants. Vet Med Czech 2002; 47: 199-210.

[17] Antunovic Z, Speranda M, Steiner Z, Vegara M, Novoselec J, Djidara M. Blood metabolic profile of Tsigai sheep in organic production. Krmiva 2009; 51: 207-212.

[18] Ramprabhu R, Chellapandian M, Balachandran S, Rajeswar $\mathrm{JJ}$. Influence of age and sex on blood parameters of Kann goat in Tamil Nadu. Indian J Small Rumin 2010; 16: 84-89.

[19] Bani IZA, AI-Majali AM, Amireh F, Al-Rawashreh OF. Metabolic profile in goat does in late pregnancy with and without subclinical pregnancy toxemia. Vet Clin Pathol 2008; 37: 434-437. http://dx.doi.org/10.1111/j.1939-165X.2008.00076.x

[20] AOAC. Official Methods of Analysis ( $17^{\text {th }}$ ed.). Association of Official Analytical Chemists, Arlington, VA. Washington DC 2000.

[21] Perera BMAO, Abeygunawardena $H$, Thamotharam $A$ Kindahl $H$, Edqvist LE. Peripheral changes of estrone, progesterone and prostaglandin in the water buffalo. Theriogenology 1981; 15: 463. http://dx.doi.org/10.1016/0093-691X(81)90089-3

[22] Kamonpatana M. Determination of endocrine patterns and their applications in the swamp buffalo. In: In the Use of Nuclear Techniques to Improve Domestic Buffalo Production in Asia. IAEA, Vienna, Austria 1984; p. 51.

[23] Momongan. Parturient behaviour and placental characteristics of cows. Revue d'Elevage et de Medecine veterinaire des Pays Tropicaux 1990; 43(1): 105-109.

[24] El-Belely MS, Zaki K, Grunert E. Plasma profiles of progesterone and total estrogens in buffaloes (Bubalus bubalis). J Agri Sci 1988; 111: 519-524.

\section{http://dx.doi.org/10.1017/S0021859600083726}

[25] Pathak MM, Janakiraman K. Serum progesterone during pregnancy in Surti buffaloes. Indian J Anim Sci 1990; 60: 1331-1333. 
[26] Arora RC, Pandey RS. Changes in peripheral plasma concentrations of progesterone, estradiol-17(1) and LH during pregnancy and parturition in the buffalo (Bubalis bubalis). Gen Comp Endocrinol 1982; 48: 403-410.

http://dx.doi.org/10.1016/0016-6480(82)90153-8

[27] Prakash BS, Madan ML. Peripheral plasma estradiol-17(1), progesterone and cortisol in buffaloes induced to calve with dexamethasone and vetoestrol. Anim Reprod Sci 1984; 11: 111-122.

http://dx.doi.org/10.1016/0378-4320(86)90110-7

[28] Eissa HM, El-Belely MS, Ghoneim IM, Ezzo OH. Plasma progesterone, estradiol-17 $\beta$ estrone sulphate, corticosteroids and metabolite of PGF2 evaluation throughout pregnancy, before, during and after parturition in buffalo cows. Veter Res Commun 1995; 26: 310-318.

[29] Batra SK, Pahwa GS, Pandey RS. Hormonal milieu around parturition. Biol Reprod 1982; 27: 1055-1061. http://dx.doi.org/10.1095/biolreprod27.5.1055

[30] Barkawi AH, Shafie MM, Abul-Ela MB. Prepartum hormonal profile in Egyptian buffaloes. Buffalo J 1986; 2: 117-124.

[31] Tiwari O, Gyulai G, Nagy P, Kovacs L, Varga J, Taverne MAM. Effect of uterus position relative the pelvic inlet on the accuracy of early bovine pregnancy diagnosis by means of ultrasonography. Vet Q 1995; 17: 37-39.

http://dx.doi.org/10.1080/01652176.1995.9694528

[32] Bahga CS, Gangwar PC. Thyroid function in relation to reproductive efficiency in postpartum buffaloes (Bubalus bubalis). Arch Exper Vet Med Leipzig 1988; 43: 17-22.

[33] Bahga CS. Plasma progesterone concentration and function relative to thyroid activity in postpartum buffalo (Bubalus bubalis). Vet Res Commun 1989; 18: 407-417. http://dx.doi.org/10.1007/BF00402560

[34] Pahwa GS, Pandey RS. Gonadal steroid hormone concentrations in blood plasma and milk of primiparous and multiparous pregnant and non pregnant buffaloes. Theriogenol 1983; 19: 491-505.

http://dx.doi.org/10.1016/0093-691X(83)90170-X

[35] Arya ML, Madan ML. Effect of stage of pregnancy on circulating thyroidal hormones among Karan Swiss and Murrah animals. Indian J Dairy Sci 2001; 39: 128-131.

[36] Aboin AC, Cooke RF, Vieira FVR, Leiva T, Vasconcelos JLM. Effects of bovine somatotropin injection on serum concentrations of progesterone in non-lactating dairy cows. Livest Sci 2013; 154: 240- 245.

http://dx.doi.org/10.1016/j.livsci.2013.03.007

[37] Gulay MS, Hayne MJ, Libonei M, Belloso TI, Wilcox CJ, Head $\mathrm{HH}$. Low doses of bovine somatotropin during the transition period and early lacation improves milk yield; efficiency of production and other physiological responses of Holstein Cow. J Dairy Sci 2004; 87: 948-960.

http://dx.doi.org/10.3168/jds.S0022-0302(04)73239-7

[38] Eisemann JH, Hammond AC, Bauman DE, Reynolds PJ, Mccutcheon SN, Tyrrell HF, Haaland GL. Effect of bovine growth hormone administration on metabolism of growing hereford heifers: protein and lipid metabolism and serum concentrations of metabolites and hormones. J Nutr 1986; 116: 2504-2509.

[39] McShane TM, Schillo KK, Estienne MJ, Boling JA, Bradley NW, Hall JB. Effect of recombinant DNA-derived somatotropin and dietary energy intake on development of beef heifers: II. Concentrations of hormones and metabolites in blood sera. J Anim Sci 1989; 67: 2237-2244.

[40] Zvorc ZVM, Susic V, Gotal JP. Haemotological and biochemical parameters during pregnancy and lactation in souls. Vet Archiv 2006; 76: 245-253.

[41] Bauman DE, Vernon RG. Effects of exogenous bovine somatotropin on lactation. Ann Rev Nutr 1993; 13: 437-442. http://dx.doi.org/10.1146/annurev.nu.13.070193.002253
[42] Etherton TD, Louveau I, Sorensen MT, Chaudhuri S. Mechanisms by which somatotropin decreases adipose tissue growth. Am J Clin Nutr 1993; 58: 287S.

[43] Sallam SMA, Nasser MEA, El-Waziry AM, Yousef MI. Economics of Using Recombinant Bovine Somatotropin in Small Ruminants. J Appl Sci Res 2005; 1(2): 156-160.

[44] Annexstad RJ, Oiterby DE, Linn LG, Hanse WP, Soderholm CG, Wheatstone JE. Somatotropin treatment for a second consecutive lactation. J Dairy Sci 1990; 73: 2423-2427. http://dx.doi.org/10.3168/jds.S0022-0302(90)78927-8

[45] McGuffey RK, Green HB, Basson RP, Ferguson TH. Lactation response of dairy cows receiving bovine somatotropin via daily injection or in a sustain release vehicle. J Dairy Sci 1990; 73: 763-771. http://dx.doi.org/10.3168/jds.S0022-0302(90)78729-2

[46] Crooker BA, McGuire MA, Cohick WS, Harkins M, Bauman $\mathrm{DE}$, Sejrsen K. Effects of dose of bovine somatotropin on nutrient utilization in growing dairy heifers. J Nutr 1990; 120: 1256-1260.

[47] Laurent F, Vignon B, Coomans D, Wilkinson J, Bonnel A. Influence of bovine somatotropin on the composition and manufacturing properties of milk. J Dairy Sci 1992; 75: 22262229.

http://dx.doi.org/10.3168/jds.S0022-0302(92)77983-1

[48] Reese DE, Peo ERJ, Lewis AJ, Hogg A. Serum chemical values of gestating and lactating swine: Reference values. Am J Vet Res 1984; 45: 978-980.

[49] Kudlac E, Vick Z, Halonsek A, Studencik B, Nedlbalkova J. Zmeny $\mathrm{V}$ biochemicke skladbe kove prosinc $\mathrm{v}$ pureperin. Vet Med 1988; 33: 401-410.

[50] Oldenbroek JK, Garssen GJ, Jonker LJ, Wilkinson JID. Effects of treatment of dairy cows with recombinant bovine somatotropin over three or four lactations. J Dairy Sci 1993; 76: 453-467.

http://dx.doi.org/10.3168/jds.S0022-0302(93)77366-X

[51] Baldi A. Manipulation of milk production and quality by use of somatotropin in dairy ruminants other than cows. Domest Anim Endocrinol 1999; 17: B1-B7. http://dx.doi.org/10.1016/S0739-7240(99)00030-2

[52] Siget JA, Sommer A, Petrikovic P. Influence of somatotropin on level of Insulin, T3, T4, TSH, bST in blood serum of dairy cows at various levels of crude protein in feed. Ann Zootech 1995; 44: 155-160. http://dx.doi.org/10.1051/animres:199505245

[53] Johnson HD, Manalu W, Spencer-Johnson KJ. Effects of somatropin on milk yield and physiological responses during summer farm and hot laboratory conditions. J Dairy Sci 1991; 74: $1250-1262$.

http://dx.doi.org/10.3168/jds.S0022-0302(91)78281-7

[54] Bouda J, Boubek, Toth J, Juraskova D. Milk yield, composition and behaviour of biochemical parameters, following bST application. Monbatshefte fiir veterinarmedizin 1991; 46: 767-769.

[55] Graf FD, Schans J, Meyer M, Krausslich J. Effect of recombinant bovine somatotropin (rbST) on physiological parameters and on milk production in German Fleckvieh cows. J Vet Med A 1991; 38: 621-628. http://dx.doi.org/10.1111/j.1439-0442.1991.tb01057.x

[56] Chadio SE, Menegatos J, Zervas G, Goulas C, Deligeorgis $\mathrm{S}$, Kalogiannis D. Pituitary responsiveness to gonadotropin and thyrotropin-releasing hormones in goats treated with recombinant bovine somatotropin. Small Rumin Res 2002; 46: 149-157. http://dx.doi.org/10.1016/S0921-4488(02)00188-8

[57] Schams D, Grat F, Meyer J, Graule B, Mauthner M, Wollny C. Changes in hormones, metabolites and milk after treatment with sometribove (Recombinant Methiomyl bST) in Deutsches Fleckvieh and German Black and White cows. J Anim Sci 1991; 69: 1583-1592. 
[58] Hung NN, Prakash BS. Influence of gestation on blood plasma concentrations of oestrone and oestrone sulphate in Karan Swiss cows and Murrah buffaloes. Br Vet J 1990; 146: 449-456.
[59] Pichaicharnarong A, Loypetjra $P$, Chaiyabutr N, Usanakarnkul S, Djurdjevic DJ. Thyroid activities of nonpregnant, pregnant, postpartum and newborn swamp buffaloes. J Agric Sci Camb 1982; 98: 483-486. 